\title{
Induction Program: An Effort to Improve Professionalism of Novice Principals
}

\section{Tutik Susilowati}

Universitas Sebelas Maret

susilowatitutik@staff.uns.ac.id

\section{Article History}

accepted 31/01/2021

\begin{abstract}
School principals had a very important role to create schools which passed Indonesian students who were expected to be smart and competitive so that they could compete in industrial revolution era 4.0. Being school principals was not an easy challenge, especially for novice principals. Transition from teachers to principals inflicted several problems. Therefore, induction program was needed by novice principals. The purpose of this article was to develop an understanding on the concept of induction program for novice principals as an effort to develop professionalism. This article was written based on the result of literature review on novice principals, induction program, and some relevant studies. This article concluded that induction program prepared novice principals to succeed as school principals who were capable to do their roles, main tasks, and functions so that their professionalism was developed. Novice principals would through professional learning process in which they learned to adapt themselves from being teachers to being school principals.
\end{abstract}

Keywords: induction, novice principals, professionalism

\begin{abstract}
Abstrak
Indonesia menjadi cerdas dan kompetitif yang siap bersaing di era revolusi industri 4.0. Menjadi kepala sekolah merupakan sebuah tantangan yang tidak mudah terutama pada awal menjabat. Transisi dari guru ke kepala sekolah banyak meimbulkan masalah. Untuk itu perlu adanya program induksi bagi kepala sekolah pemula. Tujuan artikel ini adalah mengembangkan pemahaman tentang konsep program induksi bagi kepala sekolah pemula sebagai upaya untuk menumbuhkembangkan profesionalitas. Artikel ini ditulis berdasarkan pada hasil literatur review tentang kepala sekolah pemula, program induksi dan kajian yang relevan. Artikel ini menyimpulkan bahwa program induksi mempersiapkan kepala sekolah pemula agar berhasil menjadi kepala sekolah yang mampu menjalankan tugas, pokok, dan fungsinya sehingga bertumbuhkembang profesionalismenya. Kepala sekolah pemula akan melalui proses pembelajaran professional dimana mereka belajar menyesuaikan diri dari guru menjadi kepala sekolah.
\end{abstract}

Kata kunci: Induksi, Kepala Sekolah Pemula, Profesionalisme

Social, Humanities, and Education Studies (SHEs): Conference Series https://jurnal.uns.ac.id/shes

p-ISSN 2620-9284 e-ISSN 2620-9292 


\section{INTRODUCTION}

School principal is one of important components to improve education quality. Principals are responsible for the practice of learning process, school administration, teachers and education staffs, facilities and infrastructure management, and school funding. There is no good school led by bad principal. Therefore, school principals have to be professionals.

In order to realize professional school principals in Indonesia, the Government published (Permendiknas Number 13 Year 2017 about the Standard of School/ Madrasah Headmaster, 2017). This regulation describes about the qualifications of school/ madrasah principals and five standard competence to acquire, namely personality, social, managerial, supervision, and entrepreneurship. Besides that, (Permendiknas Number 28 Year 2010 about the Teacher Assignment as School/ Madrasah Headmaster, 2010) was also published. This regulation explains about the preparation and the development of the career of school/ madrasah principals. Nowadays, those regulations are revised and resulted in (Permendikbud Number 6 Year 2018 about Teacher Assignment as Principal, 2018).

As the following step of Permendiknas Number 13 Year 2017, the Government conducted several programs, such as Principals Candidates Preparation Program (PPCKS), Continuous Professionalism Development Program for Principals (PKB), Principal Competition Reinforcement Program (PKKS), Principal Individual Reinforcement Program (PPIKS), Learning Principal (KSP), and so on. However, those programs did not show the expected result. Generally, competence acquirement of Indonesian principals was still low. The result of competence mapping conducted by The Institution of Principal Development and Empowerment (LPPKS) in 2010 showed that the social competence acquirement of principals was low. In 2015, the Institute of Education Human Resource Development and Education Quality Warrantor (BPSDM\&PMP) conducted Principals Competence Assessment (UKKS) consisting of managerial, supervision, and entrepreneurship competences and the result was not satisfying with national average score of 59.6 (Improving the Quality of School Principals, 2017).

Being school principals is not easy, especially in the early period of assignment. In Indonesia, before assigned as school principals, they are to participate in Principals Candidates Preparation Program (PPCKS). PPCKS is a process of providing school/ madrasah principal candidates consisting of recruitment as well as education and training (workshop) for them. They are taught about principal competence and school management through workshop. However, they still find several obstacles in leading schools. Based on the research (Susilowati, 2020), it is showed that novice principals (principals assigned for not more than two years) found several problems related to adapting with new environment, facilities and infrastructure condition, teachers and education staffs, school fund, and school leadership.

Principals, in their early assignment period, have to learn about their role, main tasks, and function, negotiate role transformation challenge, and develop their own leadership style. They have to adapt with their new responsibility and authority. With their new role, school principals face many defiance and have to adapt in a short period of time. The reviews on some literatures show that some defiance faced by novice principals are tasks overload, isolation, being a leader, and culturalization, and technical skill (Hoerr, 2005; Rooney, 2000; Willer, C., and Recht, 2011). Newly 
assigned principals often feel burdened and stressed, lack of competence and skill in handling so many expectations. Therefore, induction program is needed.

Induction program for novice principals is a series of activities of orientation, development, and problem solving practice in the learning/guidance and counseling process for novice principals in schools they are assigned. Many countries have conducted induction program for their novice principals and succeed (Bush, 2018), while Indonesian Government does not have induction program yet. Novice principals have to feel comfortable in their new role and manage through transformation role happening in their inner self as well as in the individuals around them. Teachers, students, parents, and government have new high expectations. Therefore, induction program is needed by novice principals as an important support in doing their role (Daresh, 2001, 2006). Novice principals position is determining so that it is rational for conducting induction as an important precondition to gain success and prepare an effective leadership (Bush, Tony, Less Bell, 2009; Daresh, 2006; Hall, 2008). This purpose of this article is to give an understanding on the process of induction program for novice principals as an effort to develop professionalism.

\section{RESULT AND DISCUSSION}

Induction is one of operating function steps in human resources management, which was employees preparing step. Induction is conducted after selection and recruitment steps are done. Generally, induction is defined as a process of preparing individuals to be successful in their initial position (Gergens, 1998). Byars and Rue in (Mabaso, 2012) define induction "... as the introduction of new employees to the organization, their work units, and their jobs." Employees induction is a series of activities to change the attitude of new employees so that they can adapt themselves with organizations' rules. Induction is basically the task of employers to their employees so that their new employees are aware that they shall obey organizations' rules and do their jobs well. Induction is a professional learning process in which someone learns to adapt himself to be better and competent related to their occupation.

Everybody in new environment needs to adapt to avoid cultural shock that can obstruct his performance. The same thing applies to novice principals who face new work environments. Principals who adapt well area able to do their main jobs and functions more easily. Therefore, induction program is needed. Induction is related to all the treatments programed to train novice principals. Based on (Bodger., 2011), induction is "the act or process of training novice principals; the initial experiences of the new principal; a systematic organizational effort to minimize problems confronting new principals." While (Villani, 2006) says that "Induction is a multidimensional process that orients new principals to a school and school system while strengthening their knowledge, skills, and dispositions to be an educational leader." Induction program provides structure and support needed to maximize the effectivity of new leaders because they will face many difficulties at school. Novice principals can learn from experienced principals and give better support for teachers in their effort to improve the learning process of their students.

Induction program prepares novice principals so that they are capable to do their main tasks and functions that their professionalism is developed. Novice principals will go through all the professional learning process in which they learn to adapt themselves from being teachers to be principals. While the definition of novice principals are principals assigned as principals for the first time (initially being teachers) 
with not more than two years of term of office. Two-years period is used as the standard because the performance of novice principals assigned for the first time will be assessed in their second year (Permendikbud Number 6 Year 2018 about Teacher Assignment as Principal, 2018). Induction program for novice principals are very important. Principals assigned need support and intensive training because their first year determines their success as principals; hence, it is important that they do their first jobs well. Induction help novice principals to understand and deepened their new roles. Some literatures have identified the important role of principals in leading their schools especially in developing and organizing their teachers, creating learning culture at schools by formulating schools' clear vision, and leading initiative reformation that will improve students' learning process. The role of principals is important in students learning and the development of school; hence, the position of principals is often seen as burden and too hard for novice principals. It is why giving support for novice principals is an important precondition for success (Daresh, 2006; Hall, 2008). For novice principals, their first year or early term of office is the most difficult time in doing their main jobs and functions so that induction program is needed. (Legotlo, 1994) states that the purposes of induction are as follows:

a. making a newly assigned principal felt accepted and safe;

b. helping novice principals to do their role effectively and efficiently;

c. encouraging web and collaboration between novice principals and senior principals;

d. preparing students learning by upgrading managerial skill of novice principal;

e. giving chance for novice principals to learn how to upgrade their skill;

f. increasing self-awareness and technical as well as social skill;

g. giving chance for novice principals to motivate themselves more;

h. helping novice principals to adapt themselves with new environment and early work culture;

i. giving information to the novice principals about the society around school, school system, students, and students organization; and

j. introducing novice principals to all school stakeholders.

(Eddy, 2004) state that the main components of induction program include program structure, content, process, guidance, and evaluation. The followings are the explanation of each component:

a. Program structure

Program structure is a series of sequence activities as an entity in the implementation of induction program. Program structure is designed based on what were to achieve, how to achieve, and the form of activities conducted to achieve the purpose. The next step is determining the time, method, material, executor, and assessment. Program structure shall combine e-learning, mentoring, and group routine meeting between novice principals. Training program for novice principals is to design accurately, planned carefully, profoundly done, and is focused on the students' achievement and how to achieve.

b. Content

Content is the subject matter or the curriculum which is structured and organized in induction program, containing principals' key competition. The curriculum in the program is designed sequentially, cumulative, and based on the participants' level of knowledge (Peterson, 2002). Program curriculum shall be coordinated and compatible to increase the learning process. During the program, the participants are required to collect data from the work place they are connected to their experiences and finally arrange the actions. 
The subject matter of induction shall cover all the things related to the needs and the problems faced by novice principals. (Cheney, G., \& Davis, 2011) identifies some important skills in the frame of main competition given in induction program, such as cultural competence, innovation and the management of change, learning leadership, organizational leadership, facilitation and communication competence, the ability to use data to increase teaching and learning, thinking system, work culture, operating management, human resources management, and selfleadership.

c. Guidance

Guidance is leadership activities given by senior principals or supervisors to novice principals in order to increase professionalism. Mentoring is the most general component in novice principals' induction. Many countries provide guidance to novice principals, both formal and informal (Foundation, 2012; Hudson, 2009). Informal guidance is spontaneous relationship pushed by mentees' needs or informal tasks, without purpose, activities, or result explicitly stated (Gergens, 1998). Some studies conclude that there is a specific place for informally and formally guidance to help novice principals to complete their learning process (Gergens, 1998).

Guidance give important support to novice principals. Most of the researches related to the satisfaction on induction or career, focused on guidance - the most general component of new main induction (Lashway, 2003). (Foundation, 2007) states that generally their research found that both mentor and mentee tend to felt satisfied with their mentoring experiences. (Daresh, 2006) writes that there are strong benefits for novice principals if the mentoring was conducted well. The benefits are higher motivation and work satisfaction, higher pride and productivity, and higher confidence.

d. Evaluation

Evaluation is a whole assessment on induction program conducted. The evaluation shall be thorough and continuous so that the program will be effective and efficient. More attention shall be given in evaluation. Formative and summative evaluation discussing on the impacts to school are really helpful; they are ideally lead by institution that is not depended on the program.

An effective induction has to be designed to help novice principals facing difficulties existed (Rooney, 2000; Villani, 2006; Walker, 2006). Tasks and functions of principals have been developed to be "a very complex position and demanded instructional and leadership skill" (Cheney, G., \& Davis, 2011); hence, novice principals shall fulfill significant qualification to face difficulties in their initial position (Hoerr, 2005; Willer, C., and Recht, 2011). Based in the research on effective induction practice, (Lashway, 2003) identifies three characteristics of effective induction program, as follows:

a. Induction program shall be compatible with principals' needs, which main focuses is helping novice principals seeing global picture of school and learning process.

b. An effective induction program shall give more than one guidance involving main web of principals, professional development, and higher stakeholder.

c. Induction program is called effective if it is combined with school programs.

Tough most novice principals were given chance to participate in some induction activities, the characteristics and the quality of the experience given to the principals might varied (Bloom, G., Castagna, C., and Warren, 2003; C, Elsberry., and Bishop, 1993; Chadwick, K., and Howley, 2002; Crocker, C., and Harris, 2002; Foundation, 
2007; Gergens, 1998; National Association for Elementary School Principals, 2003). Therefore, the induction activities are to base on the socio-cultural background, the characteristics, and the conditions of the schools where the principals are assigned.

Induction program for novice principals had been applied in some foreign countries. Many countries, such as United States of America, England, some countries in Europe, and South Africa, had applied it. United States of America had 30 induction programs. The scheme of some states in US utilized a set of standards as the basic for the content and the evaluation of their program. The most common standard adopted was the one provided by Interstate School Leaders Licensure Consortium (ISLLC) having six main elements, such as school vision development, school culture and conducive learning program, students learning and professional staff development, organization and operating management, external environment, principals character, as well as the understanding on politics, social, economic context, law, and culture existed in the country.

English government provided fund for induction program since 1992 and it succeed. The main steps of induction program developed in England were needs assessment, induction training program, guidance, new vision program, and module. While some countries in Europe had many induction programs for their novice principals, both obligatory or optional. Austria was the country obligating induction program, while Denmark and Sweden made it optional. Germany and Swiss provided both obligatory and optional. Generally, induction program in those countries had three main components, such as professional leadership profile, colleague web, and mentor support. In South Africa, induction program was conducted for two years containing some steps of workshop about many things related to principals jobs, mentoring by senior principals, and seminar with institution of principals development, all principals web, and novice principals web (Legotlo, 1994).

\section{CONCLUSION}

Well adapted principals are able to do their roles, main tasks, and functions more easily. Therefore, induction program is needed. Induction refers to all treatments programed to train novice principals. Induction program could help novice principals in doing their role, main tasks, and functions so that their professionalism is developed. The main components of induction program are program structure, content, guidance, and evaluation. Therefore, it is important to model continuous learning concept, reflection, and learning community development. The use of learning treatment, group problem solving, and learning group is useful and could maximize principals' potentials to create supporting learning community. 


\section{REFERENCES}

Bloom, G., Castagna, C., and Warren, B. (2003). More than mentors: Principal coaching.

Bodger., C. L. (2011). Novice Principals' Perceptions Of Beginning Principal Support And Induction(doctoral dissertation).

Bush, Tony, Less Bell, and D. M. (2009). The Principles of Educational Leadership \& Management (2nd editio). Sage Publicatio.

Bush, T. (2018). Preparation and induction for school principals: Global perspectives. Management in Education 1-6 2018 British Educational Leadership, Management \& Administration Society (BELMAS). https://doi.org/10.1177/0892020618761805

C, Elsberry., and Bishop, H. (1993). Perceptions of 1st year elementary principals in three southeastern states regarding principal induction programs.

Chadwick, K., and Howley, C. (2002). Networking for the nuts and bolts: Rural principals.

Cheney, G., \& Davis, J. (2011). Gateways to the principalship: State power to improve the quality of school leaders. https://eric.ed.gov/?id=ED535990.

Crocker, C., and Harris, S. (2002). Facilitating growth of administrative practitioners as mentors. Journal of Research for Educational Leaders, 1(2), 5-20. https://www2.education.uiowa.edu/archives/jrel/spring02/Harris_0107.htm

Daresh, J. (2001). Leaders helping leaders: A practical guide to administrative mentoring. Thousand Oaks, CA: Corwin Press.

Daresh, J. (2006). Beginning the principalship: A practical guide for new school leaders. Thousand Oaks, CA: Corwin Press.

Eddy, D. and B. B. (2004). Innovation in headteacher induction. National College for School Leadership. https://dera.ioe.ac.uk/5083/2/D5083New.pdf

Foundation, W. (2007). Getting principal mentoring right. NY: The Wallace Foundation. https://www.wallacefoundation.org/knowledge-center/pages/getting-principalmentoring-right.aspx.

Foundation, W. (2012). The making of the principal: Five lessons in leadership training. NY: The Wallace Foundation. https://www.wallacefoundation.org/knowledgecenter/Documents/The-Making-of-the-Principal-Five-Lessons-in-LeadershipTraining.pdf

Gergens, B. (1998). The importance of informal mentoring in acquiring the principal and throughout principal induction. ProQuest Dissertations \& Theses database. (UMI No. 9902799)

Hall, P. (2008). Building bridges strengthening the principal induction process through intentional mentoring. 89(6)(Phi Delta Kappan), 449-452. http://www.pdkmembers.org/members_online/publications/archive/pdf/k0802hal.p df,

Hoerr, T. R. (2005). The Art of School Leadership. Alexandria, VA: Association for Supervision and Curriculum Development. https://eric.ed.gov/?id=ED509050

Hudson, J. (2009). A Perceptional Analysis of The South Carolina induction program as perceived by program participants [Clemson University]. ProQuest Dissertations \& Theses database. (UMI No. 3389248)

Improving the Quality of School Principals, (2017).

Lashway, L. (2003). Inducting School Leaders. Inducting School Leaders, ERIC Digest. https://files.eric.ed.gov/fulltext/ED479074.pdf

Legotlo, M. W. (1994). An Induction Programme For Newly-Appointed School Principals In dspace.nwu.ac.za/bitstream/.../Legotlo_MW_TOC.pdf?.

Mabaso, C. M. (2012). The effectiveness of an induction programme for newly 
appointed staff at Coastal KZN FET College. http://hdl.handle.net/10321/773

Permendiknas Number 28 Year 2010 about the Teacher Assignment as School/ Madrasah Headmaster, (2010).

Permendiknas Number 13 Year 2017 about the Standard of School/ Madrasah Headmaster, (2017).

National Association for Elementary School Principals. (2003). Making the case for principal mentoring. https://www.naesp.org/sites/default/files/LeadershipMatters.pdf

Peterson, K. (2002). The Professional development of principals: Innovations and opportunities. Educational Administration Quarterly, 38(2), 213. journals.sagepub.com/doi/10.1177/0013161X02382006

Permendikbud Number 6 Year 2018 about Teacher Assignment as Principal, (2018).

Rooney, J. (2000). Survival skills for the new principal. Educational Leadership, 68(1), 77-78. https://eric.ed.gov/?id=EJ614618

Susilowati, T. and S. W. (2020). Challenges Encountered and Supports Neededby Novice ElementarySchoolsPrincipalsin Indonesia. International Journal of Advanced Science and Technology, 29(6). http://sersc.org/journals/index.php/IJAST/article/view/19421

Villani, S. (2006). Mentoring and induction programs that support new principals (Thousand O). Corwin Press.

Walker, A. and H. Q. (2006). Beginning principals: balancing at the top of the greasy pole. Journal of Educational Administration, 44(4), 297-309. https://doi.org/10.1108/09578230610674921

Willer, C., and Recht, D. (2011). What kinds of support do new principals want? Association of Curriculum and Development Express. 7(1), 1-3. 